J. Anim. Prod. U.A.R., Y, No. 1-2, 73-84 (1967).

\title{
INEFFECTIVENESS OF ESTROGEN-PROGESTERONE HORMONE TREATMENT IN EVOKING UDDER GROWTH IN BUFFALO HEIFER
}

\author{
By \\ Ahmed S. El-Shetkh, Ahmed A. Hassan and Omar Y. Abdallah \\ Departments of Animal Production and Food And Dairy Technology, \\ Ain shams University, Cairo, U.A.R.
}

\section{SUM MAR Y}

\begin{abstract}
Six Egyptian buffalo heifers were subeutaneously injected daily with $100 \mathrm{mg}$. progesterone and $100 \mu \mathrm{gg}$. estradiol. Three out of them were cycling and were given the hormone injections for 90 days. No response was noticed neither in the udder glandular tissue nor in the teats. The size of the ovaries, however, decreased and no structures were detected on their surfaces. A fourth heifer was 60 days pregnant when subjected to the hormone treatment for 37 days which apparently caused abortion between the second and the third week of injection period. No signs of udder growth were observed during such period as well as during a period of 60 days following treatment. Another 150 days pregnant heifer was injected for 120 days by the same hor. monal combination. This heifer delivered a calf 270 days old and no milk was yieled after calving. During the injection period and for 30 weeks post treatment no signs of estrus were observed and no significant external changes were observed neither in the udder size nor in the glandular tissue. The sixth heifer was 161 days pregnant when subjected to 120 days hormone treatment; it calved after 291 days producing only $213 \mathrm{kgs}$ of milk during 168 day lactation period. The udder growth did not respond to such treatment and non-significant ovarian structures or heat symptoms were observed throughout the 31 weeks after the last injection.
\end{abstract}

\section{INTRODUCTION}

Researches in physiology of lactation are usually directed towards the finding of the hormonal mechanisms controlling the development of the mammary gland itself, and into the factors infuencing the secretion and ejection of milk from glands so formed. Studies on the hormonal induction of udder growth and laetation in goats (Minxner and Turner, 43, Cowie et al, 52) and calves (Sykes and Wrenn, 51) show that the secretary tissue of the udders developed by treatment with estrogen and progesterone is histologically more normal than that of those developed by Folley et al. (40). The ratio of these two hormones for the optimal growth of labule alveolar system in mice, rats and dogs is 1 estrogen to 1000 or more of 
progesterone (Elliot and Turner, 53, Yamada et al, 54, in mice), (Elliot and Turner, 53, in rats) and (Trentin et al, '52, in dogs). In dairy calves, Yamamoto and Turner, 55, Williams et al, 55, Turner et al, 56 , williams and Turner, 59, and Turner, '59, injected $100 \mathrm{mg}$. progesterone and $100 \mathrm{ug}$. estrogen daily for a period of 180 days for determining the optimum ratio and dose of the two ovarian hormones and their synergism for growth of the udders of heifers. Similar investigations, unfortunately, have not been. carried out in buffaloes ; it was therefore thought desirable to make some observations on the effectiveness of such ovarian hormones in evoking udder growth in buffalo heifers. It seemed important to start with clarifying the physiological causes of the common problem of the mature buffalo heifer that usually shows poorly developed udder even after calving. We have, accordingly, carried out two experiments on the effects of the administration of combined estrogen and progesterone in evoking the growth of the glandular tissue in the udders of pregnant and nonpregnant Egyptian buffalo heifers.

\section{MATERIALS AND METHODS}

Animals : Six Egyptian buffalo heifers belonging to Ain shams Faculty of Agriculture Experimental Station, were divided into two groups and subjected to two treatments:

Group 1. Comprised three heifers 20-24 months old (Nos. 180, 188 and 255). These heifers were selected to be used in this treatment after being checked twice daily with an active bull and showed at least one complete estrous cycle. Meanwhile, they were examined by rectal palpation prior and allthrough treatment period in order to determine the condition of the reproductive organs.

Group 11. ineluded three pregnant heifers about 4 years old. Two animals (Nos. 214 and 223) were 150 and 161 days pregnant and the third one (No.95) was 60 days pregnant Average gestation period in buffaloes 316;6 according to Mohammed, 65).

Hormones: progesterone USP*, (P) and Estradiol USP** (E) was used and dissolved in maize oil to make a concentration of $50 \mathrm{mg}$. (P) and $50 \mu \mathrm{g}$. (E) per cc. The solution in oil was prepared by dissolving the crystalline progesterone (or estradiol) in pure other and then the maize oil was added gradually. The flasks containing the mixture were then put into an automatic shaker for $8 \mathrm{hrs}$. then refluxed to evaporate the ether.

Experimental procedure : One daily injection of $100 \mathrm{mg}(\mathrm{P})$ and another daily injection of $100 \mu \mathrm{g}$. (E) wer subcutanecusly injected in the neck region.

* Eurnished by Mann Research Laboratories Inc., New York.

** Furnished by Nutritional Blochemicals Corporation, Cleveland Ohio. 
In the first experiment, it was planned to inject the two ovarian hormones in 3 cycling heifers for a period of 90 days with the assumption that this treatment period might be sufficient to stimulate the growth of the udder glandular tissue prior to pregnancy, so that when pregnancy insues a considerable udder development might be attained either spontaneously or with the help of additional hromone treatment during the second half of gest ation.

It was kept in mind the possibility that such heifers injected with hormones may not conceive readily and therefore the second experiment was also planned In the second experiment, a heifer 60 days pregnant as well as two other heifers 150 and 161 days pregnant were used in view of stimulating the udder development in early and advanced pregnant heifers. With regard to the first heifer, the 60 days pregnancy was considered adequate for the establishment and attachment of placenta. It was intended to subject this heifer to the hormone treatment for 3 months since in normal pregnancy the growth of the lobule-alveolar system takes place during the first two thirds of gestation period (Turner, 59). This heifer, however, received the hormone treatment for only 37 days then stopped when the interruption of pregnancy was detected between the second and third weeks of the injection period. The two heifers in advanced pregnancy were injected with the combined hormones for 4 months to evoke the lobule-alveolar growth in the second half of pregnancy.

Index of Udder Growth: Two considerations has been taken in account in deciding the required index for udder growth. First, the value of the animal precludes a direct estimation of the extent of mammary gland growth. which requires sacrificing the animals at the end of the experimental growth stimulation period. Second, the maximum daily milk yield when considered as an index for udder development, is influenced by several factors including the condition of the animal, hormonal status and the extent of gleandular growth. Furthermore, the initiation of lactation by means of estrogenic hormones is still liable to some criticism (Turner, 59). On the other hand much attention has been paid to morphological studies of the artificially developed udder by methods specially developed for the purpose.

The changes in the udder were determined biweekly using the palpation method adopted by Swett et al ('55). The udders in the later stage of glandular development were measured using an ordinary standard metric ribbon for obtaining the whole length of each half and the maximum width and depth of quarters. The length and the maximum diameter of teats were measured. using a steel Caliper. In the nompregnant heifers, the changes in the genital organs were determined weekly by rectal palapation to make digital measurements of uterus and ovaries.

\section{RESULTS AND DISCUSSION}

\section{ExPERIMENT 1.}

\section{1.-Response of the Mammary Glands to Hormone Treatment.}

No changes were observed in the udder shape, size, position, firmness or the amount of fat deposition. In no case there was any evidence of mammary 
gland response to the doses employed as all udders in the treated group did not differ from the control group. The teats did not show any significant change neither in their lenght and diameter nor in their placement during the treatment period. The failure of the combined estradiol and progestorone treatment, under the conditions of this experiment in producing significant mammary growth can be clarified according to the following considerations:

(1) The slow development of the udders in buffalo heifers seems to be innate in this species, as no significant development was detected in the udders of the control heifers. It is a known fact that the interaction between estrogen and progesterone with respect to mammary gland gorwth varies murkedly in the different zoological species (Courrier, 50 ). This is by no means curious as species differ in the age of attaining their body and sexual maturity which is correlated with the degree of development in their udders. Among the same species it is observed that individuals differ in size and type of tissue present in the udder which could be attributed to both inherited factors as well as other factors including the development in the functional activity of the endocrine glands which in turn could be affested by many factors (Jacobsohn, 61).

(2) The udder may be the least sensitive reproductive part to hormone "pplication in the buffalo, since the udder of the experimental heifers showed $n o$ response to hrmone treatment while the uterus and ovaries responded to it significantly. Courrier ('50), projected the differential sonsitivity of the receptor organs in hormonal interactions.

(3) Although the heifers used in this study, were all of relatively good size yet their reproductive organs were relatively small. El-Sheikh ('62) noticed that the low level of nutrition affests markedly the development of the reproductive organs in the buffalo heifers. According to Leathem ('61), definite effects of nutrition have been observed on mammary growth, the steroid stimulation of the mammary gland was found to be influenced by nutritional factors. Trehtin and Turner ('41), showed that as food intake decreased, the amount of estradiol required to produce a minimal duet growth was proportionately increased. On the other hand inanition, did reduce the content of hypophyseal lactogen in the rat, according to Meites and Reed ('49).

(4) It is possible that the failure of the udders of sexually mature heifers used, to respond to the hormone treatment is due to the lowered sensitivity of buffalo udders. Anterior pituitary hormones seem to be essential for the growth-promoting actions of estrogen and progesterone. The results of the present work agree well with those of Sykes and Wrenn ('50). They used the dairy heifers to study the type of development attained by stilbestrol or stilbestrol plus progesterone alone and in combination with pituitary extracts. They found that the failure of steroid hormones to produce alveolar development comparable to that produced by the combined action of steroids and pituitary extracts could have been a result of inadequate sensitization or maturation of the rudimentary mammary tissues by pituitary hormones. 
Thereupon, they consluded that estrogen or estrogen plus progesterone will produce alveolar development at any stage, but a period of sensitization by pituitary hormones is necessary before their effects may be realized. A situation somewhat analogous to this can be visualized as occurring during normal pregnaney in cattle. Until the third or foruth month of pregnancy the udders of heifers consist solely of an extensive system of ducts (Sykes and Wrenn, '5p). This rather prolonged period may be a period of extension and maturation of udder rudimentary tissues primarily under the influence of pituitary hormones since the amounts of steroid hormones secreted during this interval are relatively low. The rapid development of alveoli during the latter two-thirds of pregnancy could be a result of the previous maturation combined with the increased secretion of steroid hormones which occurs during pregnancy (Sykes and Wrenn, '50).

The Foregoing is in line with what has been concluded by Folley ('61), as the pituitary hormones rocooperation. with ovarian hormones seem necessary for the experimental paduction of normal mammary growth similar to that occurring during pregnncy. Early, petersen ('48) cited that there is a considerable evidence that prolactin plays an important role in mammary growth. Recently, such role has been greatly clarified through stutying the effect of suckling on mammary development, while suckling elicits prolactin release from the anterior pitaisary in several species (Grosvenor and Turner '57a,b,e, Resee and Tumer, '37, Seyle et al, '34, Seyle and Mckeown, '34) it promotes mammary derelopment and lactation (Soyle, '34, Seyle el al, '34, Seyle and Nekeown, '34a,b).

(5) An assmmption of antagonism between the estradiol and progesterone used in the present experiment could be ruled cut for at least two considerations. First, the ratio of estradiol to progesterons (1:1000) as used has appeared to be the optimal ratio for full mammary gland growth in cattle and many laboratory animals as previously shown. Second, the dose levels of the hormones injected could not be considered so high to justify the assumption of antagonism. On one hand, Williams and Turner ('61) studied the effect of increased levels of ovarian hormones on the experim nntal induction of growth of the cow's udder. They found that daily injection of $200 \mathrm{mg}$. of progeste rone with $200 \mathrm{ug}$. estradiol benzoate for 180 days apparently stimulated mammary gland growth in no way greater than $100 \mathrm{mg}$. of progesterone and 100 wer. of estradiol benzoate injected daily for 180 days. On the other hand the doses used in the present experiment were capable to produce significant growth in the uterus. The ovarian hormones in their action upon uterus, have a nearly parallel effect on the associated pirenomenon of mammary growth (Folley and Malpress, '4s)

\section{$s$ \\ II.-Response of the Oraries to the Howmone Treatment:}

The results obtained from restal palpation showed that no ovarian structures were detected during the trestment period in the treated heifers, such heifers had less average ovarian size after hormone injections than before, 
while the control heifers showed normal activity during the period of experiment (table I). Significant differences $(P .<0.01)$ between the ovarian size before and after treament as well as between the treated and the control heifers were observed. Throngh the period of the injection of the ovarian hormones, estrous cycles were inhibited. The foregoing results concerning the ovarian. activity may be explained according to Ulberg et al (1951) who assumed that progesterone has a blocking effect "upon the action of gonadotrophic complex (perhaps primarily upon the LH). Béla Flerko' ('63) reviewed experimental results, that appear to support the hypothesis of a "nervous feed back control" by which sex steroids exert their action upon gonadotropin secretion. On the other hand he discussed experimental data supporting the hypothesis. that in the rat nervous elements of the anterior hypothalamus are indispensable in the "feed back mechanism" by which gonadotropin release is inhibited already by a slight (physiologic) elevation of the sex steriod level in the blood. Thus it may seem reasonable to assume that progesterone injected in the present experiment was responsible for the suppression of both the follicular development and symptoms of heat through the injection interval.

\section{Response of the Uterus to the Hormone Treatment :}

The results obtained from rectal palpation in this experiment (table II) showed that there was a significant increase $(p .<0.05)$ in the diameter of the uterine horns, such horns appeared to be normal in texture. The uterine horns of the control heifers, on the contrary, showed no significant increase in diameter. Turner ('49), stated that because of the synergestic action of estrogen and progesterone, a combination of the two hormones is more or less favourable for complete uterine differentiation than when either is given alone. Recently, Hissaw and Hissaw ('61), stated that the growth of the endometrium is greater when the two ovarian hormones are given together due to their synergestic interaction. They added that the progestational development of the endometrium, when both hermones were given, passes through the same stages as those following the injection of progesterone alone. The endometrium, however, is considerable thicker than a comparable dose of progesterone is given alone.

\section{EXPERIMENT 2.}

In this experiment three pregnant buffalo heifers (60,50, 161 days pregnant) were injected with the two ovarian hormones used in the first experiment to study the effect of combined estrogen-progesterone hormones on mammary gland growth during early and advanced stages of pregnancy. Pregnancy was diagnosed prior to this experiment by rectal palpation.

One heifer (No. 95) received the hormone treatment starting on day 60 after conception and was continued daily for 37 days. The treatment caused the death of the embryo and its absorption between the second and the third week following the injection as detected by the tonus of the uterus and by the 


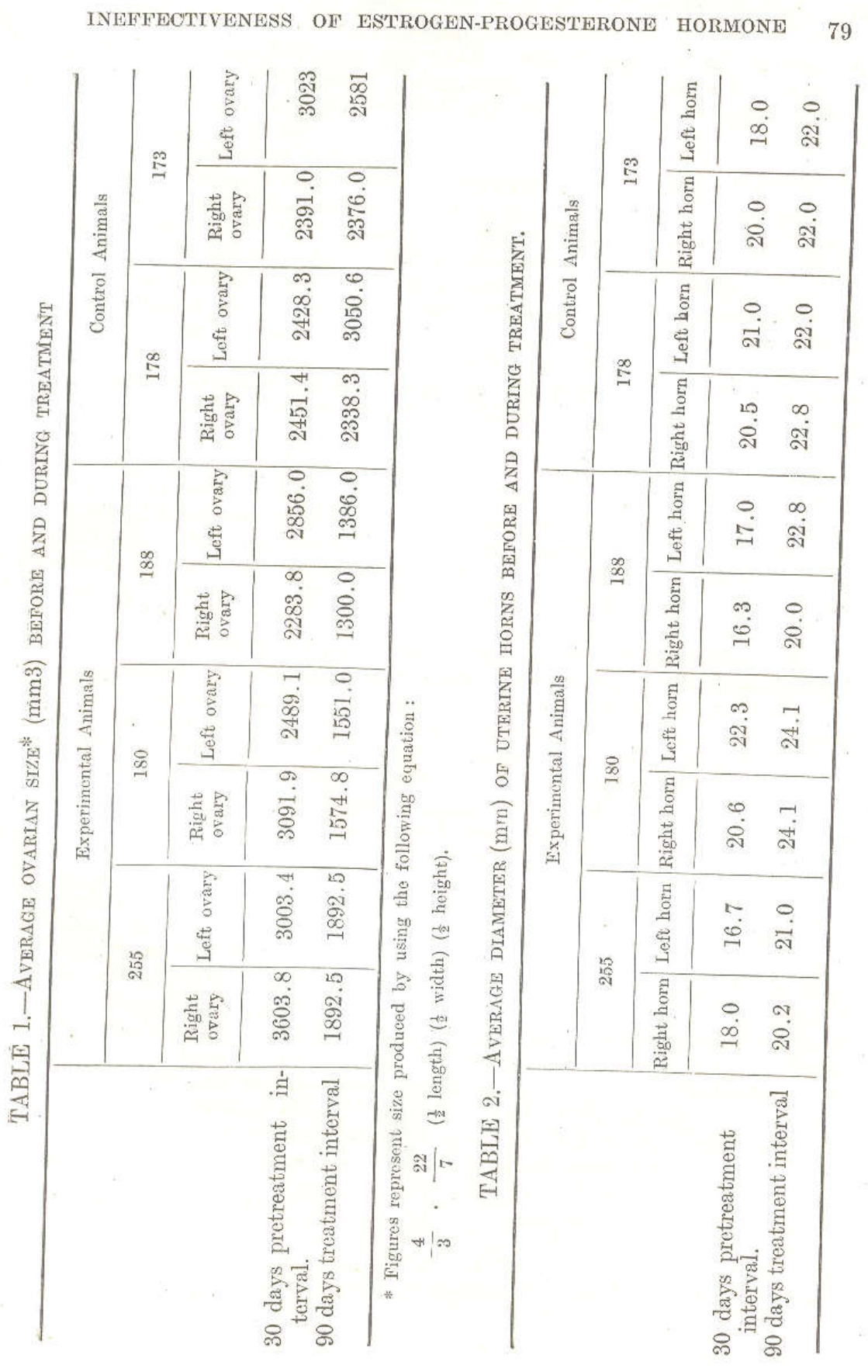


decrease in size of corpus luteum. Sixty one days after the last injection, the same heifer was observed in estrus again. No signs of udder growth were noticed neither during the treatment period nor during the 2 months post tre-
atment.

Heifer No. 214 (150 days pregnant) was injected for a period of 120 days with the combined estradiol and rpogesterone hormones. This heifer delivered a male calf 270 days old. Following parturition, it was palpated weekly for determining the ehanges in the reproductive organs. On day one after parturition only small follicles $12 \mathrm{~mm}$ in diameter were detected. The same condition of lowered ovarian activity was noticed during the 30 weeks observation period after parturition. Moreover, no signs of estrus were noticed during the 30 weeks. No significant external differences in the size of the udder between during and nontreated heifer were observed during the injection period or during the 30 weeks postpartum period. This heifer produced no milk.

The third heifer No. 223 (161 days pregnant) was injected with the same combination of hormones in the same doses for 120 days. It calved a male calf 291 days old, and produced only $123 \mathrm{kgs}$ of milk in a lactation period of 168 days. This heifer was also observed for 30 weeks postpartum and only small follicles of about $12 \mathrm{~mm}$. in diameter could be palpated. The heifer was cheeked for heat during the 30 weeks but do signs of heat were observed.

It is well known that the corpus luteum is the main source of progesterone hormone in the early stages of pregnancy, but, in advanced stages such hormone is mainly secreted by extraovarian sites, particularly, the placenta. It is possible that the hormone treatment used in this experiment inhibited the activity of the corpus luteum of pregnancy. Consequently, the inhibition of the the early stages of pregnancy was evidently responsible for the death of the foetus and its absorption during the early stages of gestation. Such inhibition was not so detrimental when the treatment started in more advanced stage of pregnancy. Furthermore, the disturbance of gestation which occurred when treatment started on day 60 of gestation could be due to what was termed by Courrier ('50), "the Follicular abortion" which, as Courrier bel eves, is due to some antagonism between estradiol and progesterone injected. Courrier ( 50 ), stated that estrogen is able to prevent the action of pregesterone on the muccsa of the uterus in the mouse, rabbit, guina pig, cat and rat. Although estrogen when injected alone in pseudopregnant and pregnant rabbits and rats (Bradbury, '61, Hammond Jr. and Robson, '51) would act as a luteotrophic agent possibly through its effect on A.P. to release the secretion of luteotropic hormone maintaining C.L. hormone secretion yet when estrogen was injected with progesterone as in the present experiment in levels and doses and in the doses injected were apparently not the optimal levels and doses that would be necessary for maintenance of pregnancy in the

According to Folley ('61) and Jacobsohn ('61), it is well known now that the hormones of anterior pituitary, ovaries and adrenal cortex are the principle hormonal mechanisms regulating mammary gland growth. Jacobsohn ('61) 
alos stated that ovarian hormones exert some effect on the pituitary gland which in turn influence the mammary glands either directly or via target organs (ovaries, adrenals). Jacobsohn added that hormones produced by hypophyseal target organs can act in turn upon the anterior pituitary gland and alter its functional activity. Whith regard to this situation further studies should be carried out to determine the possible effects of pituitary hormones when administered along with the ovarian hormones for evoking udder growth in buffalo heifer.

\section{REF ERE N CES}

Bradbury, J.T., (1961).-Direct action of estrogen on the ovary of the immature rat. Endocrinology, 68, 115.

Courrier, R., (1950).-Interactions between estrogens and progesterone. Vitam, Horm., 8 : 179.

Cowie, A.T., Folley, S.J., Malpress, F.H., And Rrchardson, K.G., (1952) Studies on the hormonal induction of mammary growth and lactation in the goat. J. Endocrinol., $8: 64$.

Emiot ; J.R., AND TURNer, C.W., (1953).- The mammary gland spreading factor. Mo. Agr. Exp. Res. Bull. 537.

EL-Sherkн, A.S., (1962).- Some Causes of lowered fertility in the Egyptian buffaloes. (unpublished data).

Flerco, Beta, (1962).-In "Advances in Neuro Endocrinology" (A.V. Nalbandoy, ed.) pp. 215-218. University of illinois Press. Urbana. Follex, S.J., (1961).-In "Marashall's Physiology of Reproduction" (A.S.
Parkes, ed.) Chap. 20, vol. $2: 3$ rd ed., Longmans, Green \& Co. London.

Folley, S.J., Malpress, F.H., (1948).-In "The Hormones". (G. Pineus, and K.V. Thimonn, ed.) p. 695, Vol. 1, Academic Press, New York.

Folifey, S.J., Scott Watson, H.M., And Botromley, A.C., (1940).-Induction of Lactation in goats with diethylstilbestrol dipropionate. J. Physiol.., 98, : 15.

Grosvenos, C.E., And Turner, C.W., (1957a).--Release and restoration of pituitary lactogen in response to nursing stimuli is lactating rats. Proc. Soc. Expt. Biol., 96, : 723.

Grosvenos, C.E., AND Turner, C.W., (1957b).-Evidence for adrenergic and componements in milk letdown reflex in lactating rats. proc Soc. Expt. Biol. Med., 9: 719.

Grostrves, C.E. AND Turver, C. W., ,(1957c).-A study of pituitary release of lactogenie hormore. J. Animal Sci., 16 : 1044.

Hammond, J. JR, And Robson, J.M., (1951).-Local Maintenance of the rabbit corpus luteum with estrogen. Endocrinology 49:384. 
Hissaw, F.L., ANd Hissaw, F.L., JR., (1961).-In "Sex and Internal Secretion" (W.C. Young, ed.) p. 556 . vol. 13 rd ed., The Williams \& Wilkins. Company, Baltimore.

JACBsoHn, D., (1961).-In "Milk : The Mammary Gland and its Secretion. (S.K. Konand A.T. Cowie, eds.) Chap. 3, Vol. 1, lst ed., Academic Press, New York and London.

Leatrem, J.H., (1961).-In Sex and Intemal Secretion (W.C. Yound, ed.) Xhap. 12, Vol. 1, 3rd ed., The Williams \& Wilkins Company, Baltimore.

Meites, J., ANd Reed, J.O., (1949).-Effects of restricted Feed intake in intact and ovariectomized rats on pituitary lactogen and gonadotrophin Proc. Soc. Exper. Biol Med. 70, 513.

Mixner, J.P., ANd Turner, C.W. (1943).-The mammogenic hormones of the anterior pituitary. 11. The lobulealveolar gorwth factor. Res Bull. Mo. Agric. Exp. Sta. No. 378

Moнamed, A.A., (1965).-The reproductive performance of the Egyptian buffalo. Thesis for the M. Sc. degree Faculty of Agriculture Ain Shams University, Egypt.

Petersen; W.E., (1948).- The hormonal control of lactation Recent Progr. Horm. Res., 21, 133.

Reece, R.R., And Turner, C.W., (1937).-The lactogenic and thyrotropic hormone content of the anterior lobe of the pituitary gland. Missouri Univ. Agr. Expt. Sta. Research Bull. No. 266. Seyle, H., (1934).-On the nervous control of lactation. Am. J. Physiol, ror :
535 .

Seyle, H.. Collip, J.B., And Thomson, D.L., (1934).-Nervous and hormonal factors in lactation. Endocrinology 18: 237.

Seyle, H., And Mckeown, T., 1934a.-The effect of mechanical stimulation. of the nipples of the ovary and the sexual cycle. Surg. Gynec. Obst.,
$\mathbf{5 9}: 886$.

Seyle, H., And Mckeown, T. 1934b.-Further studies on the influence of suckling. Anat. Record 60:323.

Swett, W.W., Book, J.H., Hathew, C.A., And Fohrman, M.H., (1955).Evaluation of Mammary gland development in Holstein and Jersey calves as a measure of potential producing capacity. Tech. Bull. No. 111 U.S. Dept. of Agric. Washington. D.C.

Sykes, J.F, AND Wrien, T.R., 1951.- Hormonal development of the mammary gland of dairy heifers. J. Doiry Sci $34: 1174$.

SYKES, J.F.. AND WRENN, T. R., (1951).-Hormonal development of the mammary gland of dairy heifers $J$. Dairy Sci., 39: 1717 . 
Trentin, J.J., And Turner, C.W., 1941.-Quantitative study of inanition on responsiveness of the mammary gland to estrogen. Endocrinology
29 : 984 .

Trentin, J.J., De Vita, J., And Gardner, W.U., (1952).-Effect of
moderate doses of estrogen moderate doses of estrogen and progesterone on mammary growth and hair growth in dogs. Anat. Rec., 113: 163.

"Turner, C.D., 1949.-In "General Endocrinology." P. 393 lst. ed., Philadelphia \& London. W.B. Saunders Comp.

Turner, C.W., (1959).- The experimental induction of the cow's udder and the initiation of milk secretion, Mo. Agric. Exp. Sta. Res. Bull. 597.

"Turner, C.W., Yamamoto, H., and Rupport, H.L., (1956).-The experimental induction of growth of the cows udder and the initiation of milk secretion. J. Dairy Sci., 39: 1717.

Ulberg L.C. Christian, R.E. and Casida, L.E.1951.-Ovarian response in heifers to progesterone injections. J. Anim Sci, 10:535.

Williams, R., Childs, O.A., Smith, D., and Turner, C.W.,(1955).-The effects of the hormones progesterone and estrogen in initiating lactation in dairy cows. J. Dairy Sci, $38: 609$,

Willtams R., And Turner, C.W.,(1959).-Study of the effects of thime on Animal Sci., $66: 1505$.

Williams R., AND TuRner C.W., (1961).--Effect of increased levels of ovarian hormones and duration on the experimental induction of growth of the cow's udder. J. Dairy Sci., 44:534.

YAMADA, J., NAGAT, J., AND NAITO, M.,(1954).-Difference in the lobule alveolar formation of the ammary gland nulliparous and multiparous mice treated with estrogen and progesterone. Endocrinological Japanica, 1:63

Yamaoto,H., AND Turner, C. W.,((1955.--Experimental udder growth and lactation in infantile dairy heifers. J. Dairy Sci, $38: 609$. 


\section{عدم جدوى المعاملة بالأستروجين - بروجسترون في تنبيه نهو الضرع في عجلات الجماموسن}

\section{المسلخص}

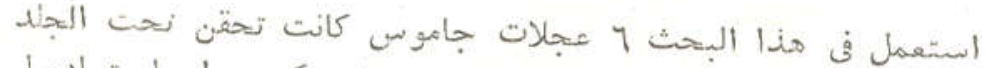

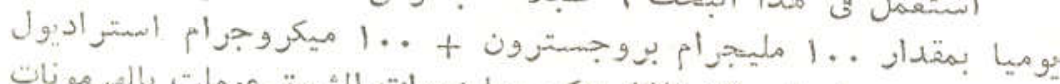

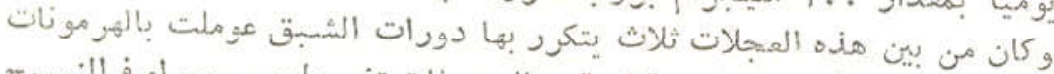

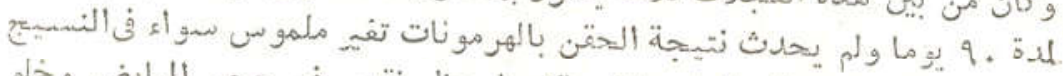

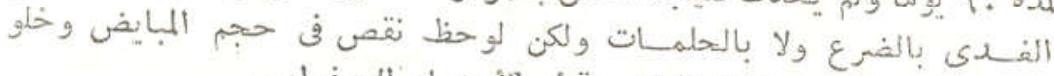

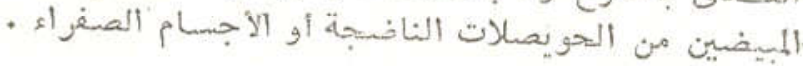

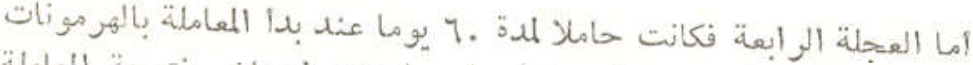

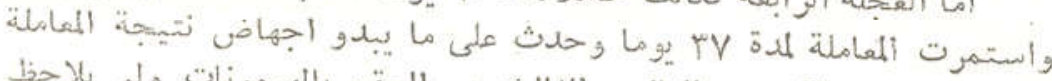

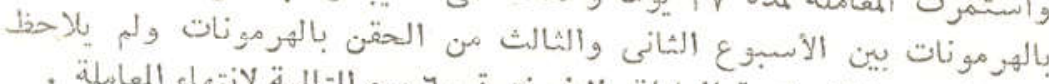

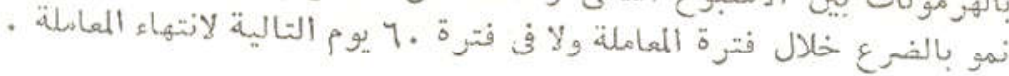

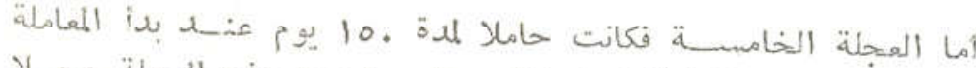

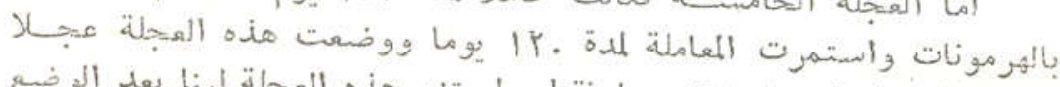

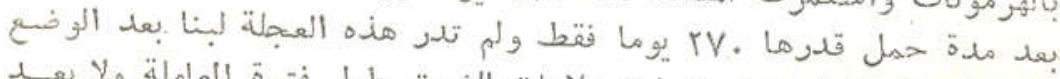

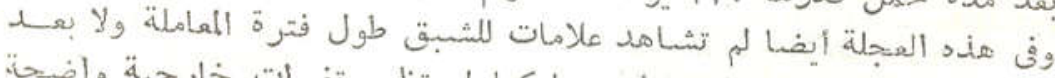

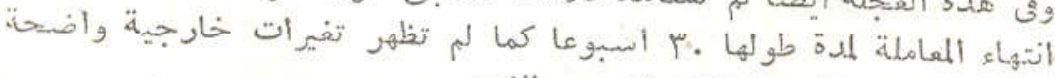

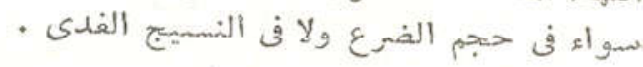

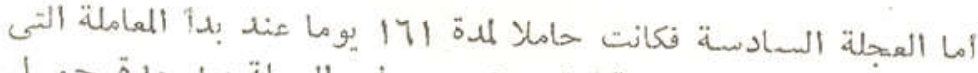

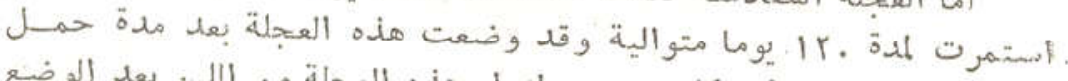

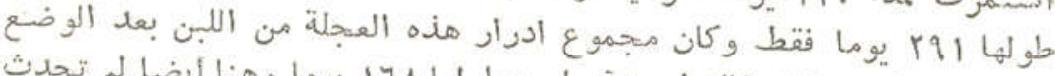

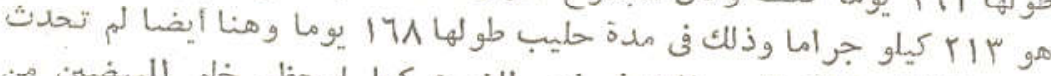

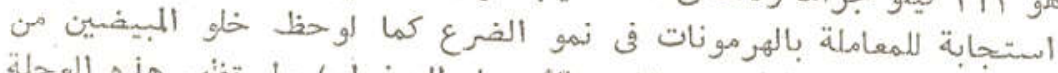

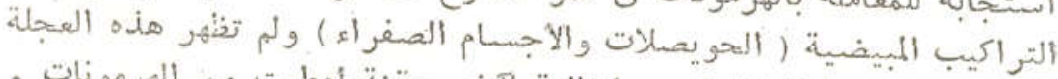

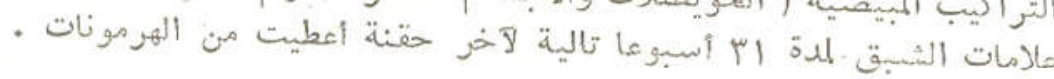

